\title{
Desain Kerangka Silabus Berbasis Tugas pada Mata Kuliah Bahasa Inggris Umum Berdasarkan Analisis Kebutuhan dan Analisis Situasi Mahasiswa Teknik Sipil UKI Toraja
}

\author{
Nilma Taula'bi' ${ }^{1}$, Markus Deli Girik Allo ${ }^{2 *}$, Elim Trika Sudarsi ${ }^{3}$ \\ 1,2,3 Universitas Kristen Indonesia Toraja \\ ${ }^{1}$ nilma@ukitoraja.ac.id, ${ }^{2 *}$ markusdeli@ukitoraja.ac.id, ${ }^{3}$ elimtrikasudarsih@ukitoraja.ac.id
}

\section{Abstrak}

Tujuan dari penelitian ini adalah menemukan Kebutuhan belajar bahasa inggris umum, dan mendesain kerangka Silabus Berbasis Tugas pada Mata kuliah Bahasa Inggris Umum Berdasarkan Analisis Kebutuhan dan Analisis Situasi Mahasiswa Tehnik Sipil UKI Toraja. Metode yang digunakan dalam penelitian ini adalah metode pengembangan (Research and development/R\&D). Responden dalam penelitian ini adalah mahasiswa Tehnik Sipil UKI Toraja sebanyak 60 mahasiswa. Dalam mengumpulkan data dalam penelitian ini, peneliti menggunakan instrumen Angket, dan Wawancara. Teknik analisis data yang digunakan dalam penelitian ini adalah menggunakan tehnik Miles dan Huberman (2002: 16). Teknik analisis data ini meliputi tiga langkah pokok yaitu: 1) reduksi data, 2) penyajian data, 3) penarikan kesimpulan, dan verifikasi. Ketiga langkah ini dilakukan secara terus menerus sejak awal. Untuk menganalisis data angket dari informasi yang sudah dikumpulkan dari responden selanjutnya dianalisis. Teknik analisis yang kami terapkan pada penelitian ini adalah dengan menggunakan persentase dan frekuensi. Hasil dari penelitian ini menunjukkan bahwa Kebutuhan belajar Mahasiswa Tehnik Sipil UKI Toraja yakni: Kegiatan Pembelajaran yang dibutuhkan meliputi Kegiatan Pembelajaran dalam bentuk tatap muka, penugasan terstruktur, kegiatan mandiri tak terstruktur. Kebutuhan mahasiswa tentang metode pengajaran yakni belajar secara berkelompok, belajar secara berpasangan, dan belajar sendiri. Topik pelajaran yang disukai dalam belajar Bahasa Inggris Umum, mahasiswa menyukai materi tentang IPTEKS, materi Bahasa Inggris Umum yang kontekstual, dan materi kegiatan sehari-hari. Desain kerangka Silabus Berbasis Tugas pada Mata kuliah Bahasa Umum Inggris didasarkan pada Analisis Kebutuhan dan Analisis Situasi Mahasiswa Tehnik Sipil UKI Toraja yang merefleksikan Kegiatan Pembelajaran dalam bentuk tatap muka, penugasan terstruktur, kegiatan mandiri tak terstruktur.

Kata Kunci: Desain Silabus, Bahasa Inggris, Analisis Kebutuhan, Analisis Situasi, Teknik Sipil

\section{Pendahuluan}

Kurikulum adalah seperangkat rencana dan pengaturan menganai tujuan, isi dan bahan pelajaran serta cara yang digunakan sebagai pedoman penyelenggarakan kegiatan pembelajaran untuk mencapai tujuan pendidikan tertentu. Toto Ruhimat dkk (Saylor, Alexander dan lewis, 1974) mengemukakan "kurikulum sebagai segala upaya sekolah untuk mempengaruhi siswa supaya belajar, baik dalam ruangan kelas, dihalaman sekolah, maupun di luar sekolah". Sukmadinata (2005) mengemukakan pengertian kurikulum ditinjau dari tiga dimensi, yaitu:"sebagai ilmu, sebagai sistem dan sebagai rencana". Toto Ruhimat dkk (S. Hamid Hasan,1988) mengemukakan bahwa kurikulum memiliki empat dimensi pengertian, yaitu: "(1) kurikulum sebagai suatu ide/gagasan, (2) kurikulum sebagai suatu rencana tertulis 
yang sebenarnya merupakan perwujudan dari kurikulum sebagai suatu ide, (3) kurikulum sebagai suatu kegiatan yang sering pula disebut dengan istilah kurikulum sebagai suatu realita atau implementasi kurikulum. Secara teoritis dimensi kurikulum ini adalah pelaksanaan dari kurikulum sebagai suatu rencana tertulis, dan (4) kurikulum sebagai suatu hasil yang merupakan konsekuensi dari kurikulum sebagai suatu kegiatan".

Guru dan dosen merupakan salah satu unsur yang penting dalam menerapkan kurikulum sebagai tenaga pendidik yang bertanggung jawab langsung dalam mengembangkan dan melaksanakan di dalam belajar mengajar. Keefektifan suatu kurikulum atau pun silabus tidak hanya tergantung pada materi ajar yang terdapat di dalamnya serta dengan kualitas dari tenaga pengajarnya tetapi juga faktor-faktor penunjang lainnya seperti sarana dan prasarana yang memadai. Keberhasilan program pendidikan melalui belajar mengajar sangat dipengaruhi oleh beberapa faktor, yaitu siswa, kurikulum, tenaga kependidikan, dana, prasarana dan sarana, dan faktor lingkungan lainnya.Apabila faktor tersebut bermutu, dan belajar bermutu pada gilirannya akan menghasilkan lulusan yang bermutu pula. Dalam hal ini saya percaya bahwa kurikulum dan sarana prasaranasangat berkaitan erat. Salah satu contoh konkritnya adalah apabila dalam kurikulum yang dipakaisaat ini menekankan dalam salah satu aspeknya mengenai membaca pemahaman melalui mendengarkan, tetapi sekolah tidak memiliki alat bantu audio pengajaran seperti radio, lab bahasa ataupun CD player maka pencapaian tujuan aspek itu tidaklah akan maksimal.

Silabus adalah rencana pembelajaran pada suatu dan/atau kelompok mata pelajaran tertentu yang mencakup standar keterampilan, keterampilan dasar, materi pokok pembelajaran, kegiatan pembelajaran, indikator pencapaian keterampilan untuk penilaian, penilaian, alokasi waktu, dan sumber belajar. Secara garis besar, silabus merupakan urutan materi ajar yang akan diberikan. Silabus yang akan dibahas pada penelitian ini adalah silabus berbasis tugas. Pemilihan silabus tersebut didasarkan pada analisis kebutuhan dan analisis situasi yang akan dilaksanakan pada Mahasiswa Tehnik Sipil UKI Toraja.

Menurut Long dan Crookes silabus berbasis tugas selalu fokus pada sesuatu yang dilakukan, bukan sesuatu yang dikatakan. Silabus berbasis tugas menekankan siswa menggunakan apa yang dipelajarinya dapat dihubungkan langsung dengan apa yang dialaminya sehari-hari. Silabus berbasis tugas berisi tugas-tugas yang siswa akan selesaikan dalam bahasa target. Tugas adalah kegiatan atau tujuan yang dilakukan dengan menggunakan bahasa seperti menemukan solusi untuk teka-teki, membaca peta dan memberikan arah, atau membaca instruksi perakitan mainan. Tugas adalah kegiatan yang memiliki makna sebagai fokus utama mereka. Keberhasilan dalam tugas adalah pencapaian hasil dan penggunaan bahasa dalam dunia nyata.

Silabus berbasis tugas biasanya, meskipun tidak secara eksklusif, menyiratkan penilaian pembelajaran siswa dengan cara mengacu pada criteria tes berdasarkan tugas, yang fokus adalah apakah atau tidak siswa dapat melakukan tugas dalam beberapa kriteria, sebagaimana ditetapkan oleh para ahli di lapangan, bukan kemampuan mereka untuk menyelesaikan item tata bahasa. Jenis tugas dibagi menjadi dua, yaitu tugas pedagogis dan tugas dunia nyata. Tugas pedagogis didasarkan pada teori SLA dan dirancang untuk memicu belajar bahasa dan strategi.

Berdasarkan latar belakang tersebut di atas, maka kami tertarik dan terinspirasi untuk melaksanakan penelitian dengan judul "Desain Silabus Berbasis Tugas pada Mata kuliah Bahasa Inggris Umum Berdasarkan Analisis Kebutuhan dan Analisis Situasi Mahasiswa Tehnik Sipil UKI Toraja". Adapun tujuan dilakukannya penelitian ini adalah untuk: Menemukan 
Kebutuhan belajar bahsa Inggris Umum dan seperti apa Situasi belajar Mahasiswa Tehnik Sipil UKI Toraja, dan Mendesain Silabus Berbasis Tugas pada Mata kuliah Bahasa Inggris Umum Berdasarkan Analisis Kebutuhan dan Analisis Situasi Mahasiswa Tehnik Sipil UKI Toraja. Silabus berbasis tugas menekankan siswa menggunakan apa yang dipelajarinya dapat dihubungkan langsung dengan apa yang dialaminya sehari-hari. Silabus berbasis tugas berisi tugas-tugas yang akan diselesaikan dalam bahasa target. Tugas adalah kegiatan yang memiliki makna sebagai fokus utama mereka. Keberhasilan dalam tugas adalah pencapaian hasil dan penggunaan bahasa dalam dunia nyata.

\section{Metode Penelitian}

Metode yang digunakan dalam penelitian ini adalah metode pengembangan (Research and development/R\&D). Borg dan Gall (1979:772) menyatakan bahwa "R\&D is a process used to develop and validate educational products." Berdasarkan definisi tersebut, penelitian ini bertumpu pada upaya memproduksi dan memvalidasi suatu produk pendidikan. Dalam penelitian ini, peneliti akan berupaya untuk menghasilkan sebuah produk pendidikan dalam wujud kurikulum yakni desain silabus berbasis tugas pada jurusan tehnik sipil UKI Toraja. Responden dalam penelitian ini adalah mahasiswa Tehnik Sipil UKI Toraja sebanyak 60 mahasiswa.

Dalam mengumpulkan data dalam penelitian ini, peneliti menggunakan instrument penelitian sebagai berikut: 1) Angket, Pengertian metode angket menurut Arikunto (2006:151) Angket adalah pernyataan tertulis yang digunakan untuk memperoleh informasi dari responden dalam arti laporan tentang pribadi atau hal-hal yang ia ketahui. Sedangkan menurut Sugiyono (2008:199) Angket atau kuesioner merupakan tehnik pengumpulan data yang dilakukan dengan cara memberi seperangkat pertanyaan atau pernyataan tertulis kepada responden untuk dijawab. Wawancara, Wawancara merupakan pertemuan dua orang untuk bertukar informasi dan ide melalui tanya jawab sehingga dapat dikontruksikan makna dalam suatu topik tertentu. (Sugiyono, 2010: 317). Dalam penelitian ini, wawancara dilakukan oleh peneliti untuk mengetahui apa saja kebutuhan belajar dan situasi belajar mahasiswa tehnik sipil UKI Toraja.

Dalam penelitian kualitatif seperti yang dianjurkan oleh Miles dan Huberman (2002: 16) analisis data meliputi tiga langkah pokok yaitu: 1) reduksi data, 2) penyajian data, 3) penarikan kesimpulan, dan verifikasi. Ketiga langkah ini dilakukan secara terus menerus sejak awal. Data dari informasi yang sudah dikumpulkan dari beberapa sumber selanjutnya dianalisis. Teknik analisis yang akan kami terapkan pada penelitian ini adalah dengan menggunakan persentase dan prekuensi.

\section{Hasil Penelitian \& Pembahasan}

\section{Kebutuhan Belajar Bahasa Inggris Umum dan Situasi belajar Mahasiswa Teknik Sipil}

Analisis kebutuhan adalah langkah pertama dalam desain program dan menyediakan validitas dan relevansi untuk semua aktivitas desain program berikutnya (Johns, 1991). Informasi ini harus mencakup hasil yang diinginkan atau yang diharapkan dari program berkualitas tinggi, peran penilaian, status saat ini prestasi siswa dan konten program yang sebenarnya. Informasi tersebut juga harus mempertimbangkan keprihatinan dan sikap guru, administrator, orang tua dan juga peserta didik. Sedangkan data sampel harus mencakup penilaian, pelajaran dari guru, tugas, nilai pada tes standar negara, buku teks yang digunakan, persepsi siswa dan umpan balik dari orang tua. Setelah melaksanakan penelitian dengan memberikan angket pada responden, maka dapat dideskripsikan Kebutuhan belajar bahasa 
inggris Umum dan seperti apa Situasi belajar Mahasiswa Tehnik Sipil UKI Toraja sebagai berikut:

Pada item Tingkat kepentingan mata bahasa inggris Umum, jelas bahwa dari 60 responden, sebanyak 50 siswa atau $83 \%$ menyatakan bahwa mereka sangat setuju pada pentingnya mata kuliah Bahasa Inggris Umum dipelajari, 10 atau 17\% setuju, dan tidak ada responden yang kurang setuju dan tidak setuju. Pada item sikap siwa pada integrasi materi dan keterampilan berbahasa Inggris, sebanyak 31 atau $52 \%$ dari 60 responden sangat setuju jika materi Bahasa Inggris Umum diintegrasikan dengan keterampilan berbahasa Inggris, 19 atau 32\% setuju, 4 atau $7 \%$ kurang setuju dan tidak ada responden yang tidak setuju pada pengintegrasian tersebut. Pada item Minat pada keterampilan berbahasa Inggris, sebanyak 16 atau 27\% dari 60 siswa yang berminat pada listening, 15 atau 24\% yang berminat pada Speaking, 14 atau 27\% yang berminat pada Reading dan sebanyak 15 atau 24\% yang berminat pada Writing. Pada item sikap responden terhadap metode ceramah, sebanyak 33 atau $55 \%$ dari 60 responden kurang setuju pada metode ceramah dalam pembelajran Bahasa inggris umum, 16 atau 27\% tidak setuju, 8 atau 13\% setuju dan sebanyak 3 atau $5 \%$ yang sangat setuju pada metode tersebut. Pada item Kegiatan Pembelajaran yang yang mahasiswa butuhkan, sebanyak 20 atau $33 \%$ dari 60 responden membutuhkan Kegiatan Pembelajaran dalam bentuk tatap muka, 21 atau 35\% untuk penugasan terstruktur, 19 atau 32\% untuk kegiatan mandiri tak terstruktur. Pada item Kebutuhan metode pengajaran, sebanyak 26 atau 43\% dari 60 responden lebih memilih belajar secara berkelompok, 14 atau 23\% memilih workshop, 11 atau 19\% memilih belajar secara berpasangan, dan 9 atau 15\% memilih belajar sendiri. Pada item Topik pelajaran yang disukai dalam belajar Bahasa Inggris Umum, sebanyak 23 atau 38\% dari 50 responden menyukai materi tentang IPTEKS, 22 atau 37\% memilih materi Bahasa Inggris Umum yang kontekstual, dan 15 atau 25\% memilih kegiatan sehari-hari.

\section{Desain Kerangka Silabus Berbasis Tugas pada Mata kuliah Bahasa Inggris Umum Berdasarkan Analisis Kebutuhan dan Analisis Situasi}

Silabus berbasis tugas merupakan silabus bahasa yang mengandung materi pelajaran yang diorganisir berdasarkan tugas-tugas atau kegiatan belajar yang harus dilakukan siswa dalam mempelajari bahasa sasaran. Secara umum, tugas dapat diartikan sebagai pekerjaan yang dilakukan seseorang untuk dirinya sendiri atau orang lain dengan mengharapkan imbalan atau tidak mengaharapkan imbalan sama sekali, seperti mengecat pagar, mengisi formulir, membeli sepatu, dan memesan tiket pesawat terbang. Dengan kata lain dapat dikatakan, tugas merupakan seratus satu macam pekerjaan yang dilakukan seseorang setiap hari. Adapun tugas dalam konteks pembelajaran bahasa diartikan sebagai aktivitas yang dilakukan seseorang sebagai hasil dari memahami bahasa. Mengenai hal ini, Richards, Platt, dan Weber dalam Farhan (2007) mengatakan "Task is an activity or action which is carried out as the result of processing or understanding language (e.i. as a response). For example, drawing a map while listening to an instruction and performing a command ... A task usually requires the teacher to specify what will be regarded as successful completion of the task." Sesuai dengan pengertian tersebut, dapat dikatakan bahwa tugas merupakan tindakan yang dilakukan oleh seseorang sebagai hasil dari pemahaman bahasa lisan yang didengar atau bahasa tulis yang dipahami. Selanjutnya, tugas tersebut harus dirinci secara jelas agar siswa dapat melaksanakannya sesuai dengan harapan yang ingin dicapai. Kegagalan dalam mendeskripsikan tugas-tugas secara jelas berarti mempersulit belajar bahasa yang dikembangkan di dalam dan di luar kelas. Untuk mempermudah tugas yang harus dilakukan siswa, guru dapat memanfaatkan topik atau tema materi pelajaran sebagai dasar elaborasi tugas- tugas tersebut. Pada penelitian ini, Desain kerangka Silabus Berbasis Tugas pada Mata kuliah Bahasa Inggris Umum didasarkan 
pada Analisis Kebutuhan dan Analisis Situasi Mahasiswa Tehnik Sipil UKI Toraja, berikut deskripsi desain kerangka silabus.

\section{SILABUS BERBASIS TUGAS MATA KULIAH BAHASA INGGRIS UMUM TEKNIK SIPIL UKI TORAJA}

[TASK-BASED SYLLABUS OF GENERAL ENGLISH FOR CIVIL ENGINEERING OF UKI TORAJA]

1. Title of Course : English

2. Course Code : MKDU 2

3. Lecturer : Nilma Taula'bi' S.Pd., M.Pd., Markus Deli G. A., S.Pd., M.Pd.

4. Weighting : 2 SKS

Elim Trika Sudarsi S.Pd., M.Pd.

5. Course Description

This course is taught to the second semester students of civil technique department as mature students of English, and it takes the students to English Using, which includes the general English.

6. Objective of the study

This course aims to improve English language skills in general (English), emphasis on reading, listening, speaking, Writing skills and language area.

7. Learning Strategy

The learning process of this course entails face-to-face, pair work, group work, and individual task. The students also have to do literature study before and after class as well as unintended papers. At the end of semester, there is a final semester test.

8. Learning Activities

Face-to face, structured assignments, unstructured self-activity (Tatap muka, penugasan terstruktur, kegiatan mandiri tak terstruktur).

9. References

a. Haryanto, S. (2003). Translation. Yogyakarta: Kanisius.

b. Alimin. (2009). Mastering English Grammar. Ujungpangkah: Planta.

c. Martinus, S. (2010). Cara Mudah Menguasai Bahasa Inggris. Jakarta Selatan: Kawahmedia.

10. Assessment Criteria

Grading components:

a. Assignment : $30 \%$

b. Quiz : :10\%

c. Attendance : $10 \%$

d. Mid test : $20 \%$

e. Final test : $30 \%$

\begin{tabular}{|r|c|c|}
\hline \multicolumn{1}{|l|}{ Score Range } & $\begin{array}{l}\text { Grade in } \\
\text { Letter }\end{array}$ & $\begin{array}{l}\text { Numeric } \\
\text { Grade }\end{array}$ \\
\hline $80,00-100,00$ & $\mathrm{~A}$ & 4 \\
\hline $65,00-79,99$ & $\mathrm{~B}$ & 3 \\
\hline $45,00-64,99$ & $\mathrm{C}$ & 2 \\
\hline $20,00-44,99$ & $\mathrm{D}$ & 1 \\
\hline $0,00-19,99$ & $\mathrm{E}$ & 0 \\
\hline
\end{tabular}

\section{Course Outline}

\begin{tabular}{|c|c|c|c|c|c|}
\hline Based Competence & Meeting & Topics & $\begin{array}{l}\text { Sub } \\
\text { Topics }\end{array}$ & $\begin{array}{l}\text { Learning } \\
\text { Activities }\end{array}$ & $\begin{array}{l}\text { Learning } \\
\text { Strategy }\end{array}$ \\
\hline \multirow{2}{*}{$\begin{array}{l}\text { After completing } \\
\text { this course, the } \\
\text { students will be } \\
\text { able : } \\
\text { 1. to identify Parts } \\
\text { of speech } \\
\text { 2. to identify } \\
\text { Nouns, } \\
\text { Pronouns, Verbs }\end{array}$} & 1 & $\begin{array}{l}\text { Course outline } \\
\text { and Course } \\
\text { contract }\end{array}$ & $\begin{array}{l}\text { a. Course outline } \\
\text { and Course } \\
\text { contract } \\
\text { b. Introduction }\end{array}$ & Face-to face & Lecturing \\
\hline & $2-3$ & Parts of speech & $\begin{array}{ll}\text { a. } & \text { Nouns, } \\
& \text { Pronouns, } \\
& \text { Verbs, and } \\
\text { b. } & \text { Adjectives } \\
& \text { Adverbs }\end{array}$ & $\begin{array}{l}\text { Face-to } \\
\text { face, structured a } \\
\text { ssignments, unstr } \\
\text { uctured self- } \\
\text { activity }\end{array}$ & $\begin{array}{l}\text { Pair } \\
\text { discussion }\end{array}$ \\
\hline
\end{tabular}




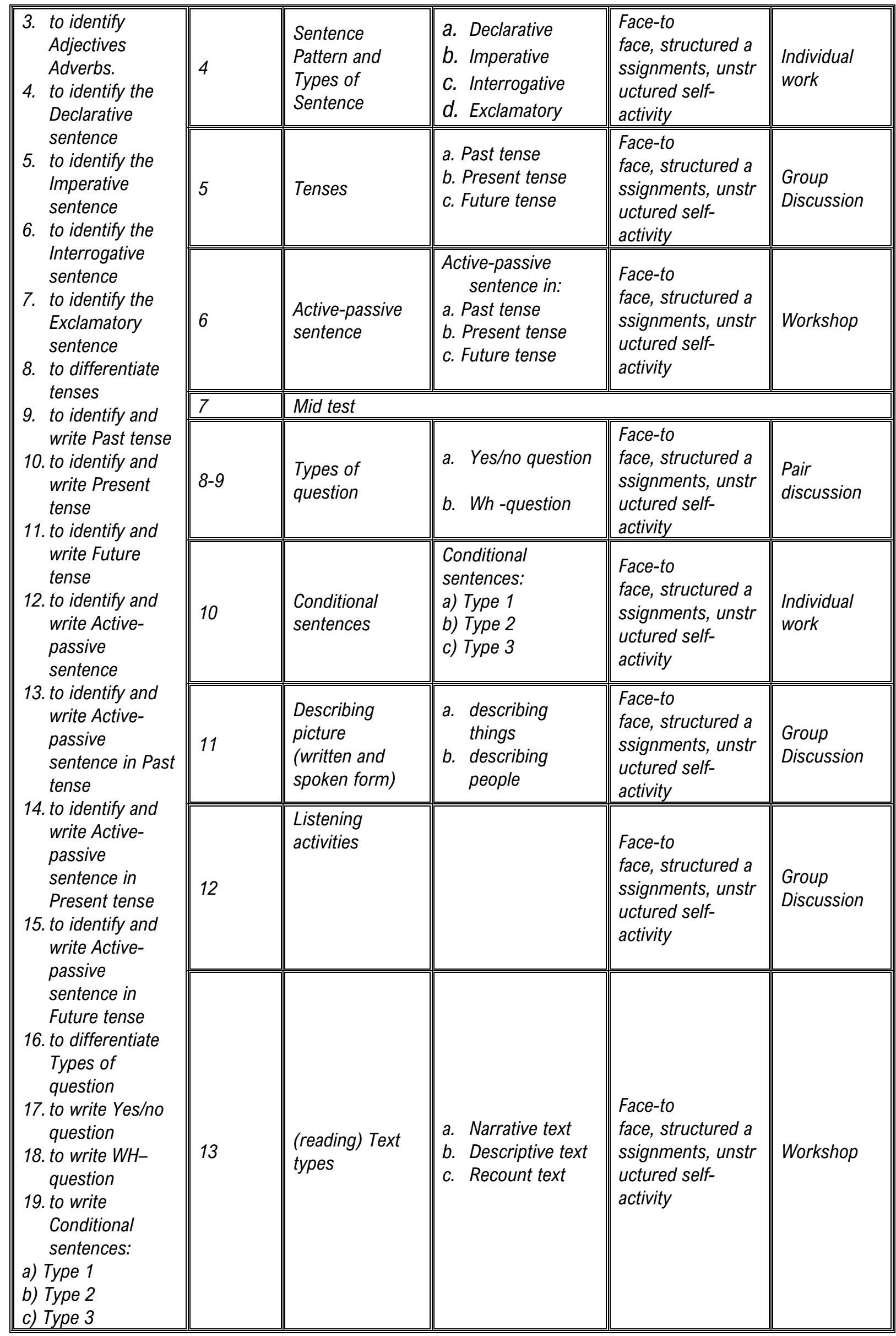




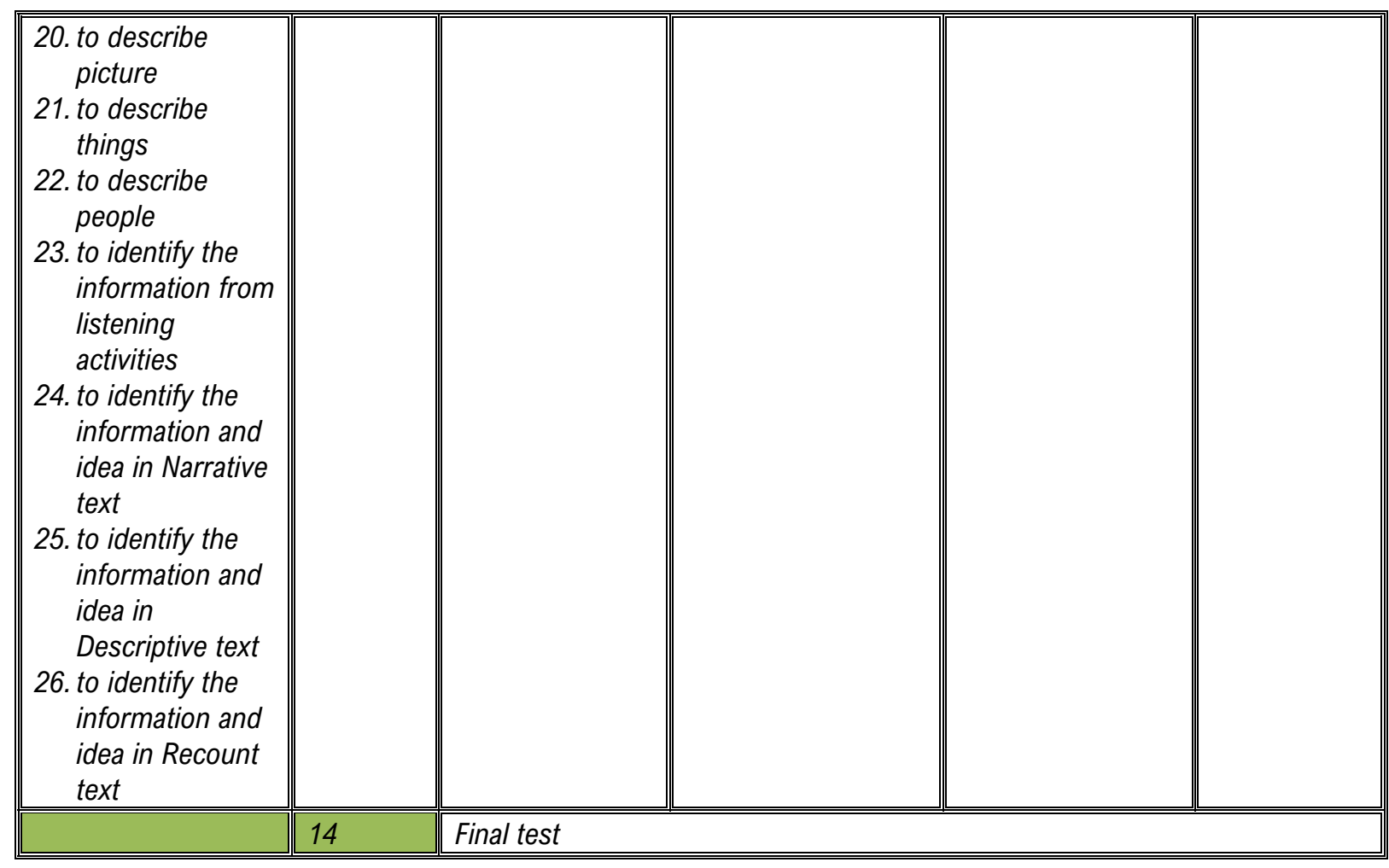

\section{Kesimpulan}

Setelah melakukan analisis data, peneliti menarik kesimpulan bahwa kebutuhan belajar dan situasi belajar Mahasiswa Tehnik Sipil UKI Toraja terdiri dari kegiatan pembelajaran, metode pengajaran, dan topik pembelajaran yang disukai. Kegiatan Pembelajaran yakni Kegiatan Pembelajaran dalam bentuk tatap muka, penugasan terstruktur, dan kegiatan mandiri tak terstruktur. Kebutuhan mahasiswa tentang metode pengajaran yakni belajar secara berkelompok, belajar secara berpasangan, dan belajar sendiri. Topik pelajaran yang disukai dalam belajar Bahasa Inggris Umum, mahasiswa menyukai materi tentang IPTEKS, materi Bahasa Inggris Umum yang kontekstual, dan materi kegiatan sehari-hari.

Desain Kerangka Silabus Berbasis Tugas pada Mata kuliah Bahasa Umum Inggris didasarkan pada Analisis Kebutuhan dan Analisis Situasi Mahasiswa Tehnik Sipil UKI Toraja yang merefleksikan Kegiatan Pembelajaran dalam bentuk tatap muka, penugasan terstruktur, kegiatan mandiri tak terstruktur.

\section{Referensi}

Majid, A. (2009). Perencanaa Pembelajaran: Mengembangkan Standar Kompetensi Guru. Bandung: Remaja Rosdakarya.

Martiyono. (2012). Perencanaan Pembelajaran: Suatu Pendekatan Praktis Merencanakan Pembelajaran Di SD/MI Berdasarkan KTSP. Kebumen: Aswaja Presindo.

Reily, T. (1988). Approaches to Foreign Language Syllabus Design. ERIC

Farkhan, M. (2007). Pengembangan Silabus Bahasa. http://www.scribd.com/doc/13618823/Pengembangan-Silabus-bahasa Diakses pada tanggal 5 Maret 2017. 